\title{
WORKPLACE WELL-BEING BERKONTRIBUSI DALAM MENINGKATKAN ENGAGEMENT KARYAWAN (Studi Literatur)
}

\section{Indah Roziah Cholilah}

\begin{abstract}
Human resources are the most important factor in achieving organizational goals. However, sometimes some kinds of problems ranging from work pressure, low-paying salary, conflicts with colleagues, lack of organizational attention and appreciation, alsobullying are often faced by these human resources, especially employees. Such problems can trigger stress on these employees. Therefore, the existing employees need to be perceived significant, not only from physiological aspects but also their psychological aspects. Individuals who are physiologically and psychologically securewill have better skills in determining attitudes, behavior and making decisions. Well-being is more than just happiness and pleasure. Well-being or a feeling of comfort in the workplace (workplace well-being) includes health which covers physiological and psychological symptoms related to the medical context. Prosperous employees will influence their personal growth, life goals, dynamic relationships establishment with the surrounding environment and the ability to make positive social contributions. Employees who have high prosperity level at work will become more cooperative, punctual,efficient, have low chance of slacking off and can work longer hours at the company. Employees willbe more enthusiastic in working, displaying high dedication and being able to concentrate fully in carrying out their duties and responsibilities. The well-being felt by employees will create positive emotional situations for their work, and become more meaningful. In the end, employees will become more emotionally attached to their workplaces.
\end{abstract}

Keywords: Workplace Well-Being, Engagement, Employees

\section{Pendahuluan}

Bagi perusahaan, sumber daya manusia memiliki peranan terpenting dalam mencapai kemajuan organisasi. Terutama pada saat menghadapi suatu persaingan yang ketat di era globalisasi seperti saat ini. Perubahan teknologi serta persaingan yang pesat tidak hanya mengandalkan produk berkualitas yang diminati oleh para konsumen, namun organisasi juga membutuhkan sumber daya manusia yang bermutu dan produktif dalam menghadapi perubahan. Dengan melakukan pengelolaan sumber daya manusia yang benar, 
maka akan menghasilkan sebuah output yang berkualitas bagi perusahaan. Selain itu, tujuan perusahaan juga akan tercapai ketika sumber daya manusianya mampu menampilkan performa kerja terbaiknya. Maka dari itu, penting kiranya bahwa perusahaan harus memperhatikan hal-hal atau faktor-faktor yang dapat menunjang performa kerja para karyawan, baik dari sisi internal maupun eksternal. Seperti misalnya kompetensi karyawan yang perlu dikembangkan, budaya dan iklim organisasi tempat dimana karyawan tersebut bekerja. Iklim organisasi yang positif, memberikan sumbangsih yang cukup besar terhadap kualitas performa karyawan. Karyawan akan menampilkan loyalitas yang tinggi dalam bekerja dan antusias dalam menyelesaikan tugasnya meski berada di bawah tekanan waktu dan pekerjaan. Penelitian telah menemukan hubungan positif antara employee engagement dan kinerja karyawan. Perusahaan dengan karyawan yang engaged memiliki retensi karyawan yang tinggi hasil dari menurunnya turn over karyawan, mengurangi niat untuk keluar dari perusahaan, meningkatkan produktivitas, profitabilitas, pertumbuhan dan kepuasan pelanggan (Markos, Sridevi 2010). Secara umum, karyawan yang memiliki kesejahteraan di tempat kerja atau workplace well-being akan merasa puas dan nyaman dalam bekerja, sehingga akan menghasilkan kinerja yang baik pula. Selain itu, mereka memiliki keyakinan atau belief terhadap apapun yang dikerjakan. Belief merupakan perasaan bahwa seseorang dapat memberikan konstribusi yang bermakna bagi pekerjaannya, organisasinya dan masyarakat secara keseluruhan. ${ }^{1}$ Terdapat hubungan antara kesejahteraan pekerja (employee well-being) dengan pendapatan organisasi. Organisasi dengan pekerja yang memiliki tingkat well-being yang lebih baik cenderung memberikan kepuasan pelanggan yang lebih baik, kesetiaan pelanggan yang lebih tinggi, profitabilatas yang lebih besar, produktivitas yang lebih baik dan tingkat turn over pekerja yang lebih rendah. Maka dari itu, workplace well-being menjadi sangat penting yang harus diperhatikan oleh pihak perusahaan. Tidak terpenuhinya kesejateraan karyawan dapat berdampak negatif terhadap perusahaan, salah satunya adalah kinerja yang buruk, sehingga dapat berdampak langsung pada hasil pekerjaan. Maka dari itu workplace well-being sangat perlu dibangun dalam perusahaan untuk menciptakan keterikatan karyawan dengan organisasi sehingga diharapkan tujuan organisasi bisa tercapai dengan baik.

${ }^{1}$ Harter, James K., (dkk): Well-being in the workplace and its relationship to business outcomes: A review of the Gallup studies. In C. L. M. Keyes \& J. Haidt (Eds.), Flourishing: Positive psychology and the life well-lived (American Psychological Association: 2003), 205. 


\section{Tinjauan Teori}

\section{Kesejahteraan di Tempat Kerja (Workplace Well-Being)}

Kesejahteraan/kenyamanan karyawan di tempat kerja (workplace well-being) adalah sebuah konsep yang relatif baru dalam ilmu manajemen sehingga konseptualisasi dan definisinya berbeda-beda. Workplace well-being atau kesejahteraan di tempat kerja adalah perasaan sejahtera yang dirasakan oleh para pekerja terhadap tempat kerjanya. Konsep workplace well-being adalah komponen aplikasi dari subjective well-being. ${ }^{2}$ Subjective well-being adalah kondisi pikiran yang positif yang melibatkan seluruh pengalaman hidup. Komponen subjective well-being mencakup kepuasan hidup, afeksi positif dan afeksi negatif.

Workplace well-being memiliki berbagai definisi yang dikembangkan karena menggunakan pendekatan yang berbeda-beda. ${ }^{3}$ Tokoh lain menggunakan istilah kesehatan dan kenyamanan (healt and well-being) kerja untuk melihat kenyamanan kerja karyawan (workplace well-being). ${ }^{4}$ Workplace well-being meliputi health, yaitu mencakup gejala fisiologis dan psikologis yang berkaitan dengan konteks medis. Selanjutnya workplace well-being, yaitu mencakup pengukuran terhadap kesejahteraan berdasarkan pengalaman hidup dan pengalaman yang berakaitan dengan pekerjaan. ${ }^{5}$ Workplace well-being adalah perasaan sejahtera yang karyawan peroleh dari pekerjaan yang terkait dengan perasaan pekerja secara umum (core affect) yang terdiri dari nilai instrinsik dan ekstrinsik dari pekerjaannya. ${ }^{6} \mathrm{Di}$ sisi lain, Workplace Well-being didefinisikan sebagai kesehatan mental karyawan yang dipengaruhi oleh pertumbuhan pribadi, tujuan hidup, hubungan positif dengan orang lain, penguasaan terhadap lingkungan, integrasi sosial, dan kontribusi sosial. ${ }^{7}$ Konsep workplace well-being merupakan konstruk yang paralel dengan konstruk subjective well-being dan psychological well-being. Konsep ini menjadi landasan dalam membangun konsep kesehatan mental karyawan (employee mental healt). Subjective well-being memiliki definisi sebagai kebahagiaan, yang digambarkan sebagai keadaan pikiran positif yang meliputi keseluruhan pengalaman hidup seorang. Hal yang membedakan

${ }^{2}$ Diener, E., (dkk): Subjective well-being: Three decades of progress. Psychological Bulletin, 125, 1999: 276-302

${ }^{3}$ Karen Danna and Ricky W. Griffin: Health and Well-Being in the Workplace: A Review and Synthesis of the Literature.Journal of Management 1999; 361

${ }^{4}$ Ibid, hal 361

${ }^{5}$ Kathryn page: Subjective Wellbeing in the Workplace, Deakin University. (Thesis: 2005), hlm 9.

${ }^{6}$ Ibid, hal 205

${ }^{7}$ Kathryn page \&Vella-Brodrick, The 'What', 'Why', and 'How' of Employee well-being (A New Model. Social Indicators Research, 90), Hal: 441 
konsep workplace well-being dengan kedua konsep lainnya adalah konsep ini menekankan pada kepuasan dan afek-afek yang berhubungan dengan pekerjaan. Afek-afek yang berhubungan dengan pekerjaan (work-related affect) terdiri dari komponen afek positif dan negatif. Dalam hal ini, kepuasan dalam bidang pekerjaan merupakan bentuk evaluasi kognitif mengenai hal-hal yang berkaitan dengan pekerjaan. Sedangkan, afek yang berhubungan dengan pekerjaan meupakan bentuk evaluasi afektif (emosional) terhadap pekerjaannya. Namun demikian kedua hal pembentuk workplace well-being tersebut sudah menjadi salah satu dalam konstruk workplace well-being sehingga tidak dapat dipisahkan unsur kognitif dan afektif dalam mengukur tingkat workplace well-being seseorang.

Psychological well-being merupakan usaha keras yang dilakukan oleh seseorang untuk kesempurnaan dan potensinya, sedangkan workplace well-being merupakan komponen yang paling dekat dengan karyawan dan lingkungan kerja. Hal ini disebabkan karena workplace well-being fokus pada kepuasan aspek-aspek pekerjaan dan work-related affect. Workplace Well-being dapat membentuk pikiran seseorang ke arah memaksimumkan prestasi kerja dan mencapai potensi diri. Lebih lanjut dijelaskan bahwa workplace well-being ditandai dengan hadirnya afek/perasaan positif. ${ }^{8}$ Terdapat aspek-aspek dari workplace well-being yang terbaik ke dalam dua dimensi atau faktor besar yaitu 5 aspek dari faktor intrinsik dan 8 aspek dari faktor ekstrinsik.

\section{Dimensi Workplace Well-Being}

Dimensi Workplace Well-Being, sebagai berikut:

\section{Dimensi Instrinsik}

Dimensi instrinsik terdiri dan aspek-aspek yang mengacu pada perasaan karyawan terkait tugas-tugas yang dimiliki dari tempat kerja mereka. Dimensi instrinsik ini terdiri dari lima aspekm yaitu:

a) Tanggung jawab dalam Kerja

Aspek ini didefinisikan sebagai perasaan yang dimiliki karyawan terhadap tanggung jawab kerja yang diberikan organisasi dan kepercayaan untuk melakukan pekerjaan dengan baik.

b) Makna Pekerjaan

Aspek ini didefinisikan sebagai perasaan karyawan bahwa pekerjaannya memiliki arti dan tujuan baik secara personal, maupun untuk skala yang lebih luas.

c) Kemandirian dalam pekerjaan

${ }^{8}$ Loc.cit, hal 8 
Aspek ini didefinisikan sebagai perasaan individu bahwa dirinya dipercaya untuk melaksanakan tugasnya secara mandiri, tanpa petunjuk dari manajemen.

d) Penggunaan kemampuan dan pengetahuan dalam bekerja Aspek ini didefinisikan sebagai perasaan bahwa pekerjaan yang diberikan memungkinkan mereka akan menggunakan pengetahuan dan kemampuan yang dimiliki.

e) Perasaan berprestasi dalam bekerja

Aspek ini didefinisikan sebagai rasa memiliki pencapaian terentu terkait dengan tujuan yang berhubungan dengan kerja.

2. Dimensi Ekstrinsik

Dimensi ekstrinsik adalah dimensi yang mengacu kepada hal-hal yang dilingkungan kerja yang dapat mempengaruhi karyawan dalam bekerja. Dimensi ini terdiri dari delapan aspek sebagai berikut:

a) Penggunaan waktu yang sebaik-baiknya.

Aspek ini didefinisikan sebagai perasaan karyawan mengenal waktu kerjanya merupakan hal yang penting karena memungkinkan karyawan untuk membentuk keseimbangan antara waktu kerja dan kehidupan pribadi (work-life balance)

b) Kondisi kerja

Aspek ini didefinisikan sebagai kepuasan karyawan terhadap lingkungan kerja seperti ruang kerja dan budaya organisasi.

c) Supervisi

Aspek ini didefiniskan sebagai karyawan terhadap perlakuan atasan, seperti perlakukan baik, pemberian dukungan, pemberian bantuan ketika dibutuhkan, umpan balik yang sesuai dengan penghargaan dari atasan.

d) Peluang promosi

Aspek ini didefinisikan sebagai kondisi lingkungan kerja yang memberikan kesempatan karyawan untuk berkembang secara profesional.

e) Pengakuan terhadap kinerja yang baik

Aspek didefiniskan sebagai perasaan karyawan bahwa di lingkungan kerja mereka, mereka telah menghasilkan kinerja yang baik dan yang tidak mendapatkan perlakukan yang berbeda.

f) Penghargaan sebagai individu di tempat kerja

Aspek ini didefinisikan sebagai perasan karyawan bahwa mereka dihargai dan diterima sebagai individu baik oleh keluarga maupun atasan mereka.

g) Upah (pay)

Aspek ini didefiniskan sebagai keuasan karyawan terhadap upah, keuntungan dan penghargaan berupa uang yang ddapatnya dan lingkungan 
kerja.

h) Keamanan pekerjaan

Aspek ini didefinisikan sebagai kepuasan dengan rasa aman di posisi pekerjaan mereka.

Disamping itu untuk meningkatkan pegawai yang memiliki kinerja yang tinggi, maka salah satu aspek yang tak kalah penting adalah memperhatikan lingkungan kerjanya. Lingkungan kerja yang mendukung, seperti sarana prasarana, kebersihan, bagunan, ruangan dan kerapihan serta hubungan yang harmonis baik dengan pimpinan dan rekan sejawat ikut andil dalam memperngaruhi peningkatan kinerja karyawan. Komitmen merupakan suatu keadaan individu dimana individu menjadi terikat oleh tindakannya. Melalui tindakan ini akan menimbulkan keyakinan yang menunjang aktivitas dan keterlibatannya. Jadi dengan memiliki komitmen terhadap perusahaan maka karyawan akan melaksanakan tugasnya dengan baik bahkan mereka semakin loyal dan setia terhadap perusahaan tersebut. Dengan komitmen yang kuat maka pekerja akan lebih memiliki kemampuan dan kemauan untuk menyelaraskan perilaku pribadi dengan kebutuhan, prioritas dan tujuan organisasi.

\section{Keterikatan Organisasi (Employee Engagement)}

${ }^{9}$ Konsep Employee Engagement dalam ranah industri organisasi memiliki berbagai macam variasi sehingga terdapat variasi definisi yang membangun konsep employee engagement. Dalam hal ini, terdapat dua definisi mengenai employee engagement. Hal ini antara lain membagi employee engagement menjadi dua konsep terpisah. Pertama adalah keterikatan terhadap organisasi dan yang kedua adalah keterikatan terhadap pekerjaan. Keterlibatan pribadi dalam mengekspresikan diri baik secara fisik, kognitif, emosi, juga merupakan bentuk dari kerikatan individu terhadap organisasinya. Employee engagement adalah komitmen emosional karyawan pada organisasi dan tujuannya. Komitmen emosional ini berarti karyawan benar-benar peduli tentang pekerjaan dan perusahaan mereka. Mereka tidak bekerja hanya untuk gaji, atau hanya untuk promosi, tetapi bekerja atas nama tujuan organisasi. ${ }^{10}$ Beberapa peneliti yang mendefinisikan bahwa employee engagement diartikan sebagai keterikatan terhadap organisasi, yang menyatakan bahwa Employee Engagement adalah; "The degree to which people commit to an organization and the therefore the impact that

${ }^{9}$ Alan M. Saks, Antecedents and Consequences of Employee Engagement (Journal of Managerial Psychology, 2006, Vol. 21 No. 7, No. 601-602).

${ }^{10}$ Brad Federman, Employee Engagement: A Road map for Creating Profits, OptimizingPerformance, and Increasing Loyality. SanFrancisco: Jossey-Bass A Wiley Imprint, 2009) hal. 37 
commitment has on how profoundly they perform and their length of tenure". Lebih lanjut, employee engagement didefinisikan sebagai kesediaan karyawan untuk memberikan waktu, pikiran dan energi di atas dan di luar apa yang dipertimbangkan memadai. Karyawan yang engaged memiliki keyakinan dan mendukung tujuan organisasi di mana dia bekerja dan mempunyai keinginan untuk berkembang dan bertahan dalam organisasi. ${ }^{11}$ Berbagai peneliti dan terori mengungkapkan bahwa employee engagement sebagai komitmen atau motivasi yang mengacu pada keadaaan psikologis di mana karyawan merasa memiliki kepentingan dalam keberhasilan perusahaan dan melakukan tugas dengan standar yang tinggi melebihi persyarakatan yang ditugaskan.

\section{Dimensi-dimensi Employee Engagement}

${ }^{12}$ Employee Engagement tersusun atas tiga dimensi, yaitu semangat (vingor), dedikasi (dedication), absorpsi (absorption) yang akan dijelaskan sebagai berikut:

1. Semangat atau vingor didefinisikan sebagai tingkat energi dan ketahanan mental yang tinggi ketika individu menyelesaikan pekerjaan, keinginan untuk menanamkan semangat pada pekerjaan, serta persisten dalam menghadapi kesulitan-kesulitan yang ditemui saat bekerja.

2. Dedikasi atau dedication adalah indentifikasi yang kuat pada pekerjaan dan mencakup perasaan yang meliputi antusiasme, inspirasi, kebanggaan, dan tantangan.

3. Absorpsi atau absorption dijelaskan sebagai konsentrasi penuh dan perasaan senang yang dirasakan individu ketika sedang bekerja, dimana individu merasa waktu berjalan dengan cepat dan sulit meninggalkan pekerjaan.

Faktor-faktor yang mempengaruhi employee engagement: work environtment (lingkungan kerja), leadership (kepemimpinan), team and Co-worker (tim dan hubungan rekan kerja), training and career development (pelatihan dan pengembangan karir), conpensation (kompensasi), organizational policies, procedures, struktures and system (kebijakan organisasi, prosedur, struktur, dan sistem) workplace well-being (kesejahteraan kerja).

${ }^{11}$ (Sumber: mencerHR. Com, dikutip dalam Truss et al, 2014)

${ }_{12}^{12}$ chaufeli dan Baker, Job demands, job resources, and their relationship with burnout and engagement : a multi-sample study. Journal of Organizational Behavior,25, hal. 293 


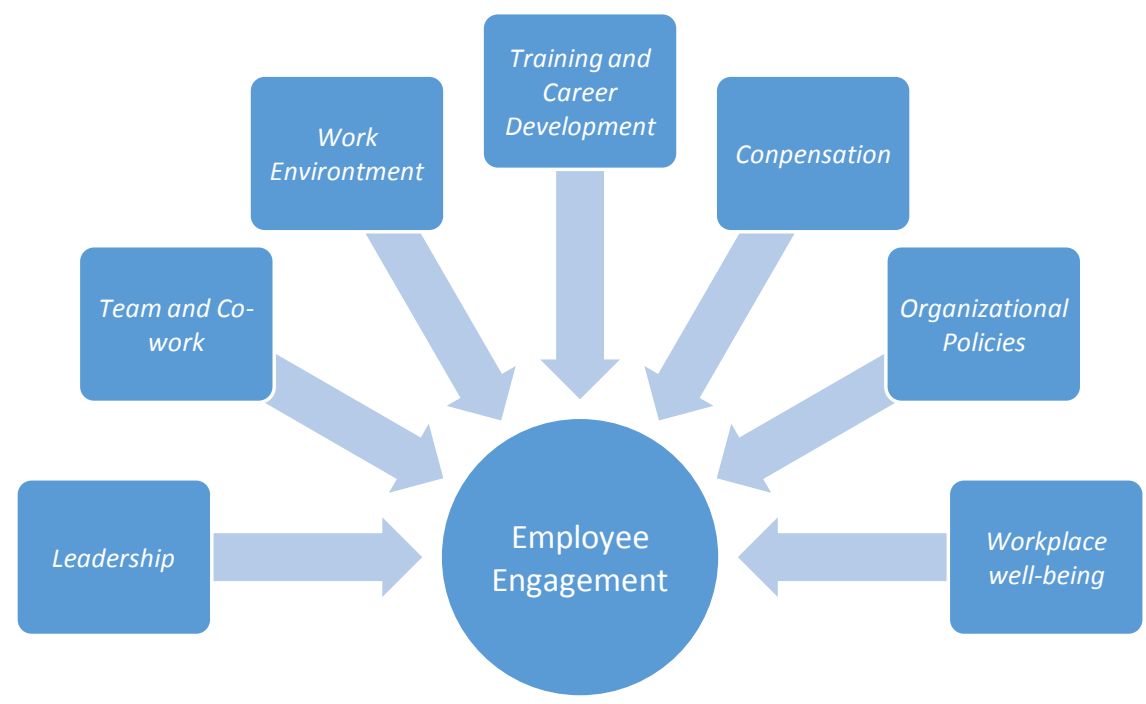

${ }^{13}$ Gambar 1 Faktor-faktor yang mempengaruhi employee engagement

${ }^{14}$ Menurut Mathis dan Jackson (2006), menguraikan beberapa faktor yang digunakan dalam mengukur kinerja pegawai, yaitu: kuantitas hasil kerja, kualitas hasil kerja, ketepatan waktu, kehadiran dan kemauan bekerjasama. Sejumlah studi menunjukkan bahwa cara penting untuk meningkatkan kinerja karyawan adalah fokus pada pengembangan employee engagement. Penelitian (Christian et al, 2011; Fleming dan Asplund, 2007; Kaya et al, 2010; Richman, 2006; Macey dan Schneider, 2008; Holbeche dan Springett, 2003; Leiter dan Bakker, 2010) lain juga menunjukan bahwa adanya pengaruh level yang tinggi pada employee engagementterhadap kinerja kerja, kinerja tugas, dan organizational citizenship behaviour, produktifitas, discretionary effort, affective commitment, continuance commitment, levels of psychological climate, dan layanan pelanggan.

${ }^{15}$ Manfaat dari employee engagement bahwa employee engagement dapat menciptakan kesuksesan bagi perusahaan melalui hal-hal yang berkaitan dengan kinerja karyawan, produktivitas, kesalamatan kerja, kehadiran dan re-

${ }^{13}$ Anitha J, "Determinants of employee engagement and their impact on employee performace". International Journal of Productivity and Performance Management, Vol. 63 Iss 3pp: 2014, hal: 308-323

${ }^{14}$ Mathis \& Jackson,. Human Resource Management, alih bahasa. (Salemba Empat. Jakarta, 2006), hal. 378

15Siddhanta dan Roy,. Employee Engagement - Engaging The 21st Century Workforce. Asian Journal of Management Research, 2010. Hal. 171 
tensi, kepuasan pelangga, loyalitas pelanggan, hingga profitabilitas.

\section{Workplace Well-Being Berkontribusi Dalam Meningkatkan Engagement Pa- da Karyawan}

Well being merupakan semua hal terpenting terkait bagaiaman seseorang berfikir, merasakan dalam menghadapi segala pengalaman kehidupannya. Oleh karena itu well-being menjadi langkah untuk mengukur dampak yang telah dimiliki organisasi pada individu. Walaupun banyak faktor yang mempengaruhi engagement pada karyawan, namun penulis hanya berfokus pada kesejahteraan di tempat kerja (Workplace well-being). Memperhatikan kesejahteraan psikologis dari karyawan adalah hal yang sangat penting bagi organisasi, karena dapat mempengaruhi bagaimana karyawan tersebut bersikap dan berperilaku, membuat keputusan, menyelesaikan permasalahan di tempat kerja serta kegiatan interaksi dengan pimpinan dan rekan sekantornya. Karyawan yang memiliki kesejahteraan yang tinggi di tempat kerja akan lebih kooperatif, memiliki tingkt absensi yang rendah, tepat waktu dan efisien, serta dapat bekerja lebih lama dalam perusahaan. Karyawan yang memiliki kesejahteraan di tempat kerja akan lebih bahagia dalam pekerjaan dan kehidupan rumah tangganya. Kesehjahteraan yang dirasakan oleh karyawan di tempat kerja, juga akan memicu rasa emosional yang positif terhadap pekerjaannya. Pekerjaan yang dilakukan menjadi lebih bermakna. Karyawan akan menciptakan hubungan yang positif antara dirinya dengan organisasi/ perusahaan lebih dekat lagi. Semangat dan dedikaskanya terhadap perusahaan akan menjadi lebih tinggi.

Dalam membangun keterikatan karyawan juga perlu memperhatikan faktor upah, kesempatan promosi, lingkungan kerja yang positif dan budaya organisasi, sikap atasan dan penguasaan yang ada serta hubungan dengan teman sekerja. Faktor tersebut telah disinggung dalam 8 dimensi workplace well-being. Membangun keterikatan karyawan juga sangat terkait dengan bagaiamana komitmen organisasi tersebut kepada karyawannya. Manfaat dari employee engagement dapat menciptakan kesuksesan bagi perusahaan melalui hal-hal yang berkaitan dengan kinerja karyawan, produktifitas, keselamatan kerja, kehadiran dan retensi, kepuasan pelanggan, loyalitas pelanggan, hingga profitabilitas. Karyawan yang memiliki kaitan kuat dengan perusahaan akan meningkatkan performansi dalam pekerjaannya untuk keuntungan perusahaan.

Pada dasarnya, temuan menunjukkan bahwa ketika organisasi melakukan banyak upaya dalam meningkatkan keterlibatan karyawan, akan banyak karyawan yang termotivasi dan mendapatkan prestasi di tempat kerja, biasanya 
karyawan akan memiliki tingkat kesejahteraan yang lebih tinggi. Individu yang sejahtera akan memiliki kebermaknaan yang tinggi dalam menjalankan tugas dan tanggung jawabnya sebagai seorang karyawan. Selain itu, organisasi yang dapat memenuhi keinginan individu, meliputi gaji/ upay, kesempatan promosi, penghargaan dan dapat memberikan keamanan kepada karyawan di prediksikan individu atau karyawan akan mendapatkan kesejahteraan psikologis di tempat kerja. Menurut Lew (20110 komitmen dikembangkan berdasarkan pada bentuk hubungan yang bersifat exhange theory, yaitu melihat adanya hubungan timbal balik antara pemenuhan kebutuhan karyawan yang diterima di tempat kerja dengan kontribusi yang telah diberikan kepada perusahaan. Sehingga karyawan yang loyal terhadap organisasi, maka perusahaan wajib memberikan ganajran atau upah yang sesuai. Karena kesesuaian upah atau penghargaan akan berkontribusi positif dalam membangun motivasi dan kesejahteraan secara psikologis karyawan. Karyawan yang memiliki kesejahteraan di tempat kerja juga akan berfungsi lebih optimal dalam pekerjaannya.

\section{Kesimpulan}

Kesejahteraan di tempat kerja (Workplace well-being) memberikan kontribusi yang positif terhadap keterikatan karyawan di tempat kerja (Employee engagement). Karyawan yang engagement tentunya akan memiliki komitmen emosional yang tinggi pada tujuan organisasi. Karyawan akan benar-benar peduli tentang pekerjaan dan organsisasi tempat mereka bekerja. Selain itu karyawan juga memiliki keyakinan dan mendukung penuh tujuan organisasi untuk berkembang dan bertahan dalam menghadapi tekanan. Karyawan yang engaged juga akan membangun komitmennya dan motivasi tinggi, merasa memiliki kepentingan dalam keberhasilan perusahaan. Karyawan yang memiliki kesejahteraan yang tinggi, diprediksikan akan mampu menunjukkan semangat kerja, dedikasi serta motivasi dalam menjalankan tugas dan tanggung jawabnya di tempat kerja. Kesejahteraan di tempat kerja tidak hanya berfokus pada kebahagiaan fisiologis saja, namun juga kebahagiaan secara psikologis. Workplace well-being meliputi kesehatan (healt), mencakup pengukuran terhadap kesejahteraan berdasarkan pengalaman hidup dan pengalaman yang berkaitan dengan pekerjaan. Ditandai dengan adanya afek dan perasaan positif yang dapat membentu pikiran seseorang dalam mencapai potensi diri dan prestasi kerja. Sikap atasan, kesempatan promosi, kesesuaian upah, budaya kerja yang positif, dan lainnya akan menciptakan keterikatan karyawan pada tujuan organisasi. 


\section{Daftar Pustaka}

Anitha J (2014), “Determinants of employee engagement and their impact on employee performance". International Journal of Productivity and Performance Management, Vol. 63 No. 3, pp. 308-323.

Bakker,A.B., Schaufeli, W.B., Leiter, M.P., \& Taris, T.W. (2008). Work engagement: an emerging concept in occupational health psychologywork \& stress, 22 (3), 187-200.

Danna, Karen. \& Griffin, Ricky. W.(1999). Health and well-being in the workplace: A review and synthesis of the Literature, Journal of management .

Federman, Brad. 2009. Employee Engagement: A Road map for Creating Profits, Optimizing Performance, and Increasing Loyality. SanFrancisco: Jossey-Bass A Wiley Imprint.

Harter, J. K., Schmidt, F. L., \& Hayes, T. L. (2002). Business-Unitlevel Relationship Between Employee Satisfaction, Employee Engagement, And Business Outcomes: A Meta-Analysis. Journal of Applied Psychology Vol.87: hal.268-79.

Harter, J. K., Schmidt, F.L., \& Keyes, C.L.M. (2003). Well-being in the workplace and its relationship to business outcomes: A review of the Gallup studies. In C.L.M. Keyes and J Haidt (Eds) Flourishing, Positive Psychology and the Life Well-lived. Washington DC, USA:American Psychological Society.

Page, K.M., \& Vella-Brodrick, D.A. (2009). The 'What', 'Why', and 'How' of Employee well-being; A New Model. Social Indicators Research, 90: 441-458.

Page, K. (2005). Subjective Wellbeing In The Workplace. Thesis. School Of Psychology Faculty Of Health And Behavioral Sciences Deakin University.

Ramadhan, N., \& Sembiring, Jafar., (2014), pengaruh employee engagement terhadap kinerja karyawan di human capital center PT telekomunikasi Indonesia, tbk, Jurnal manajemen Indonesia, vol. 14 -No. 1 April 2014

Robbins, Stephen. P. 2006. Perilaku Organisasi. Edisi Kesepuluh. PT. Indeks

Saks, A.M. (2006). Antecedents and consequences of employee engagement. Journal of Managerial Psychology,21(6),600-619.

Shimazu, \& Schaufeli (2008), “Work Engagement: An Emerging concept in occupational healt psychology". Article in Bioscience trends.

Schaufeli, W. B.Salanova, M., Gonzalez-Roma, V. \& Bakker, A.B. (2002). The measurement of burnout and engagement : A confimantory factor analytic approach. Journal of Happiness Studien, 3,71-92

Schaufeli, W. B. \& Bakker, A. B. (2004). Job demands, job resources, and their relationship with burnout and engagement : a multi-sample study. Journal of 
Organizational Behavior, 25,293-315.

Sivanathan, N., Arnold, K.A.,turner, N., \& Barling, J. (2004). Leading well: transformational leadership and well -being. Dalam Linley, P.A.\& Joseph, S. (Eds). Positive psychology in practice (241-255). New Jersey: John Wiley \& Sons, inc.

Steers, R.M dan Porter, L.W. 1983. Motivation and Work Behavior, New York: Acadaemic Press.

https://www.hrmagazine.co.uk/article-details/employee-engagement-closely-tie d-to-health-and-wellbeing, diakses pada tanggal 13 Januari 2020 pada pukul 13.07 WIB

Thomson, Neil dan Bates, Jhon. 2009. Promoting Workplace well-being; New York: Palgrave Macmillan

Siddhanta, Abhijit dan Roy, Debalina. 2010. Employee Engagement - Engaging The $21^{\text {st }}$ Century Workforce. Asian Journal of Management Research. 